\title{
PIENIACTWO SĄDOWE NA PRZYKŁADZIE SPRAW TOCZĄCYCH SIĘ PRZED SĄDEM Metropolitalnym W Lublinie
}

\section{Wprowadzenie}

Pieniactwo jako zaburzenie psychiczne nie jest jednostką chorobową. Nie zostało ujęte ani w Międzynarodowej Statystycznej Klasyfikacji Chorób i Problemów Zdrowotnych - ICD-10 (ang. International Statistical Classification of Diseases and Related Health Problems), ani w klasyfikacji zaburzeń psychicznych Amerykańskiego Towarzystwa Psychiatrycznego DSM-IV TR (ang. Diagnostic and Statistical Manual of Mental Disorders). Pieniactwo jest głównie związane z paranoicznymi cechami osobowości, czasem z psychozą, a także z osobowością niedojrzałą. Zdarza się również, że pieniactwo nie jest połączone $z$ żadnymi zaburzeniami psychicznymi, a ze zwykłym warcholstwem. Niemniej jednak w praktyce sądowej bardzo często można spotkać pieniaczy sądowych, nazywanych również kwerulantami sądowymi. Ich działania, podyktowane przekonaniem o własnej racji, roszczeniowość oraz nieustępliwość potrafią znacznie utrudnić każdy proces, w tym proces o nieważność małżeństwa, który ma na celu dojście do prawdy odnośnie do ważności lub nieważności zaskarżonego małżeństwa.

Celem niniejszego opracowania jest przybliżenie pieniactwa sądowego jako zaburzenia psychicznego, określenie jego rodzajów oraz wpływu działań pieniaczy na przebieg procesu o stwierdzenie nieważności małżeństwa. Analiza akt spraw o nieważność małżeństwa toczących się przed Sądem Metropolitalnym w Lublinie pozwoliła na stwierdzenie, iż rów-

* Dr, Katolicki Uniwersytet Lubelski Jana Pawła II; wiceoficjał Sądu Metropolitalnego w Lublinie; e-mail: g.bzdyrak@diecezja.lublin.pl. 
nież $\mathrm{w}$ tego typu postępowaniach występują pieniacze sądowi. Składają oni obszerne pisma, wnioskują o wyłączenie sędziów, a nawet posuwają się do gróźb czy też fałszywych oskarżeń w stosunku do uczestników procesu. Podkreślić należy, iż nie jest to zjawisko nowe, ponieważ już w sprawach toczących się w latach okupacji niemieckiej odnaleźć można przykłady działań pieniaczy.

\section{Pieniactwo jako zaburzenie psychiczne oraz rodzaje pieniaczy}

W języku potocznym pieniaczami nazywa się osoby, które przejawiają zamiłowanie do wszczynania sporów sądowych, przede wszystkim o błahe sprawy, co może być konsekwencją chorobliwej skłonności do dochodzenia sprawiedliwości za doznane krzywdy, urojone lub rzeczywiste ${ }^{1}$. Jak wskazuje J. Wojtasik nasilenie pieniactwa w poszczególnych krajach jest bardzo różne, a często powiązane z niektórymi cechami narodowymi. W Polsce jest zjawiskiem dosyć rozpowszechnionym, co autor ten łączy z genami i zamiłowaniem naszych przodków do procesowania się. Wyróżnia się co najmniej trzy charakterystyczne postacie pieniactwa: paranoję, psychozę i warcholstwo, przy czym tylko dwie mają podłoże chorobowe, natomiast trzecia łączy się z osobowością lub charakterem człowieka².

Pierwszy rodzaj pieniactwa jest związany z paranoją. Pieniactwo sądowe nie zostało sklasyfikowane jako zaburzenie psychiczne, jednak jego objawy zostały umieszczone w ICD-10, przy opisie jednostki diagnostycznej określanej jako „osobowość paranoiczna” (F.60.0) obejmująca osobowość ekspansywno-paranoiczną, osobowość fanatyczną, osobowość paranoidalną, osobowość pieniaczą oraz osobowość sensytywno-paranoiczną. Według klasyfikacji ICD-10 kryteriami diagnostycznymi „osobowości paranoiczno-pieniaczej” są: nadmierna wrażliwość na niepowodzenia i odrzucenie; niezdolność do wybaczania zniewag; tendencja do długotrwałego przeżywania przykrości; podejrzliwość bez uzasadnienia;

\footnotetext{
Zob. Pieniacz, [w:] M. Szymczak (red.), Stownik jezzyka polskiego, t. 2, Warszawa 1992, s. 651 .

Zob. J. Wojtasik, Kwerulant sądowy, czyli różne oblicza pieniactwa, Internetowy Serwis Informacyjny Prokuratury Okręgowej w Zielonej Górze, http://www.zielona-gora. po.gov.pl/index.php?id=36\&ida=2891 [dostęp: 29.03 .2019 r.].
} 
ujmowanie obojętnych działań otoczenia jako wrogich lub pogardliwych; sztywne poczucie własnych praw; podejrzenia dotyczące wierności partnerów i przyjaciół; przecenianie własnego znaczenia i poczucia własnej wartości; pochłonięcie wyjaśnieniami określonych wydarzeń; koncentrowanie się na niepotwierdzonych "spiskowych" wyjaśnieniach, wydarzeniach dotyczących zarówno bezpośrednio danej osoby jak i całego świata. Natomiast symptomy osobowości paranoicznej według DSM-IV TR to: trwała nieufność i podejrzliwość wobec innych, która sprawia, że motywy ich działań odbierane są jako złowrogie; bezpodstawne podejrzewanie wykorzystywania, szkodzenia lub oszukiwania; uporczywe okazywanie urazy; szybkie reagowanie gniewem i kontratakiem; niechęć do zaufania innym w obawie o wykorzystanie informacji przeciwko sobie. Osoba dotknięta zaburzeniem jest przekonana o słuszności podejmowanych działań, a niekorzystne dla niej wyroki czy rozstrzygnięcia, w jej mniemaniu, nie wynikają z braku rzeczowych argumentów lub dowodów, ale są skutkiem „spiskowania” sędziów czy innych uczestników wymiaru sprawiedliwości ${ }^{3}$.

Osoby z paranoicznym zaburzeniem osobowości mają uszkodzoną zdolność do oceny słuszności własnych przekonan. Cechuje je sztywność poznawcza, która nie pozwala przyjać im innej perspektywy, co odbija się negatywnie szczególnie na relacjach interpersonalnych. Możliwość zmiany przekonań jest bardzo słaba, nawet przyjazne relacje mogą być odbierane jako pozorne, kryjące złe intencje. Ponadto taka osoba ma bardzo wygórowane mniemanie o sobie ${ }^{4}$.

Posiadający osobowość paranoiczną nie są w stanie nawiązać trwałego przymierza małżeńskiego z uwagi na egoizm i egocentryzm oraz pojawiające się bezpodstawne podejrzenia współmałżonka o zdrady. Nieufność wobec małżonka oraz własna interpretacja wydarzeń doprowadza do rozpadu małżeństwa. W obliczu trudności lub problemów osoby te stają się nieustępliwe, agresywne, a nawet stosują szantaż lub prowokacje. Są bezkompromisowe $\mathrm{w}$ obronie swoich praw ${ }^{5}$.

3 Zob. E. Soroko, Paranoiczne zaburzenia osobowości, [w:] L. Cierpiałkowska, E. Soroko (red.), Zaburzenia osobowości. Problemy diagnozy klinicznej, Poznań 2017, s. 99; D. Jagiełło, Pieniacze sądowi $i$ ich funkcjonowanie w praktyce wymiaru sprawiedliwości, „Medyczna Wokanda" 2014, nr 6, s. 186-188.

4 Zob. E. Soroko, Paranoiczne zaburzenia osobowości, s. 110-111.

5 Zob. S. Paździor, Przyczyny psychiczne niezdolności osoby do zawarcia matżeństwa w świetle kan. 1095 n. 3, Lublin 2009, s. 96-98. 
Drugi rodzaj zaburzeń, z których wynika pieniactwo to psychozy, objawiające się przez urojenia. Są to utrwalone błędne przekonania, które trwają niezmiennie mimo przeciwnych oczywistych dowodów. Urojenia będą to również zaburzenia treści myślenia. Występują m.in. przy schizofrenii, zaburzeniach afektywnych, zespołach urojeniowych oraz parafrenii.

Trzecim typem pieniactwa, niemającym jednak podłoża chorobowego, jest tzw. warcholstwo, definiowane jako awanturnictwo, wichrzycielstwo i kłótliwość 6 . Jest ono związane przede wszystkim z osobowością (charakterem) pieniacza, jego egoizmem, poczuciem wyższości i roszczeniową postawą. Pieniacz nie uznaje innych racji, odmiennych od swoich. Cechuje go sztywność poglądów, ma własną interpretację każdego zjawiska i podejmowanej decyzji. Oczekuje od innych spełnienia jego żądań, natomiast brak odpowiedniej reakcji ze strony wymiaru sprawiedliwości powoduje jego niezadowolenie, a nawet agresję. W swoich działaniach wykazuje determinację, ma poczucie misji, chce zwalczać niesprawiedliwość, która go dotknęła, a często po prostu chce dokuczyć innym. Stąd też zamiłowanie do przedłużania postępowania poprzez pisanie donosów i odwołań oraz wniosków o wyłącznie sędziego ${ }^{7}$.

\section{Pieniactwo sądowe a prawo do sądu}

Prawo do sądu jest jednym z podstawowych praw człowieka. Sprawiedliwe rozpatrzenie sprawy $\mathrm{w}$ rozsądnym terminie zagwarantowane jest przez Konstytucję $\mathrm{RP}^{8}$. Również prawo kanoniczne ${ }^{9}$ gwarantuje wiernym możliwość dochodzenia i obrony przysługujących im uprawnieńn ${ }^{10}$.

6 Zob. Warcholstwo, [w:] M. Szymczak (red.), Stownik jezyka polskiego PWN, t. 3, Warszawa 1998, s. 612.

7 Zob. J. Wojtasik, Kwerulant sądowy...

8 Art. 45 ust. 1 Konstytucji Rzeczypospolitej Polskiej z dnia 2 kwietnia 1997 r., Dz. U. z 1997 r. Nr 78, poz. 483 z późn. zm.: „Każdy ma prawo do sprawiedliwego i jawnego rozpatrzenia sprawy bez nieuzasadnionej zwłoki przez właściwy, niezależny, bezstronny i niezawisły sąd".

9 Codex Iuris Canonici auctoritate Ioannis Pauli PP. II promulgatus. Kodeks Prawa Kanonicznego, przekład polski zatwierdzony przez Konferencję Episkopatu, Poznań 1984 (dalej: KPK).

10 Kan. $221 \mathrm{KPK}$ : „§ 1. Wiernym przysługuje legalne dochodzenie i obrona przysługujących im w Kościele uprawnień na właściwym forum kościelnym według przepisów 
Sprawowanie przez Kościół wymiaru sprawiedliwości podlega pewnej specyfice, która wynika ze słuszności kanonicznej. Rozstrzygnięcia sądowe muszą być oparte na sprawiedliwości i prawdzie obiektywnej, a sędziowie kierują się miłością, miłosierdziem i łagodnością, bez zbędnego rygoryzmu, mając na uwadze, iż najważniejsze jest zbawienie dusz ${ }^{11}$.

Oczywistym jest, iż kościelne prawo do sądu nie jest bezwzględne, ale jego ograniczenia mogą wynikać jedynie z przepisów prawa kanonicznego. Ograniczenia te mogą polegać na braku możliwości odwoływania się od niektórych rozstrzygnięć ${ }^{12}$, czy też konieczności zachowania odpowiednich przepisanych prawem terminów ${ }^{13}$.

W procesach o nieważność małżeństwa, uprawnienie do zaskarżenia ważności małżeństwa przysługuje małżonkom oraz rzecznikowi sprawiedliwości $i^{14}$. Strony procesowe mają możliwość przedstawiania dowodów na poparcie swoich twierdzeń ${ }^{15}$. Dowody powinny być pożyteczne i godziwe ${ }^{16}$.

prawa. § 2. Wierni, jeżeli zostali wezwani przed sąd przez kompetentną władzę, mają prawo, by byli sądzeni z zachowaniem przepisów prawa, stosowanych ze słusznością. § 3 . Wiernym przysługuje prawo, by nie nakładano na nich kar kanonicznych, jak tylko zgodnie przepisami ustawy".

11 Zob. T. Pawluk, Prawo kanoniczne wedtug Kodeksu Jana Pawta II, t. 4. Doczesne dobra Kościoła. Sankcje w Kościele. Procesy, Olsztyn 1990, s. 159-160.

12 Kan. 1629 KPK: „Nie ma miejsca na apelację: $1^{\circ}$ od wyroku samego Papieża lub Sygnatury Apostolskiej; $2^{\circ}$ od wyroku dotkniętego wadą nieważności, chyba że jest złączona ze skargą o nieważność według przepisu kan. 1625; $3^{\circ}$ od wyroku, który przeszedł w stan rzeczy osądzonej; $4^{\circ}$ od dekretu sędziego lub wyroku przedstanowczego, które nie mają mocy ostatecznego wyroku, chyba że jest złączona z apelacją od ostatecznego wyro$\mathrm{ku} ; 5^{\circ}$ od wyroku lub dekretu w sprawie, w stosunku do której prawo zastrzega, że rzecz powinna być jak najszybciej rozstrzygnięta".

13 Franciszek, List apostolski motu proprio "Mitis Iudex Dominus Iesus" reformujacy kanony Kodeksu Prawa Kanonicznego dotyczace spraw o orzeczenie nieważności małżeństwa (15.08.2015), Tarnów 2015, art. 4 (dalej: MIDI): „Kan. 1679. Wyrok stwierdzający po raz pierwszy nieważność małżeństwa, po upływie terminów ustalonych w kan. 1630-1633, staje się wykonalny".

14 Kan. 1674 MIDI: „§ 1. Do zaskarżenia małżeństwa są zdolni: $1^{\circ}$ małżonkowie; $2^{\circ}$ rzecznik sprawiedliwości, kiedy nieważność została już rozgłoszona, jeżeli małżeństwo nie może zostać uważnione albo nie jest to wskazane; § 2. Małżeństwo, które za życia obojga małżonków nie zostało zaskarżone, po śmierci jednego lub obojga małżonków nie może być zaskarżone, chyba że kwestia dotycząca ważności ma charakter przedprocesowy dla rozwiązania innego sporu, bądź na forum kanonicznym, bądź na forum świeckim".

15 Kan. 1526 § 1 KPK: „Obowiązek dowodzenia spoczywa na tym, który coś twierdzi”.

16 Kan. 1527 KPK: „§ 1. Mogą być przytoczone dowody jakiegokolwiek rodzaju, które wydają się pożyteczne do poznania sprawy i są godziwe. § 2. Jeżeli strona nalega, by 
W niektórych przypadkach strony nadużywają przysługujące im uprawnienia procesowe poprzez zgłaszanie znacznej liczby świadków, składanie bezpodstawnych wniosków o wyłączenie sędziego czy innych osób biorących udział w procesie, przedkładanie coraz to nowych dokumentów, niekoniecznie merytorycznie związanych ze sprawą, czy też odwoływanie się od niezaskarżalnych decyzji. Takie działania mogą wynikać z pieniactwa sądowego. Niemniej jednak, nie można odmówić pieniaczowi prawa do sądu lub ograniczać jego uprawnień procesowych wyłącznie z uwagi na jego pieniactwo. Może się bowiem okazać, iż przedkładane przez niego dowody pozwolą na dojście do prawdy obiektywnej o zaskarżonym małżeństwie. Sędziemu przysługują również uprawnienia pozwalające na zdyscyplinowanie strony, która w sposób nieuzasadniony przedłuża postępowanie. Przede wszystkim może ograniczyć zbyt dużą liczbę świadków ${ }^{17}$ lub odrzucić dowód, który jest niegodziwy, jak również wyznaczyć stronie ostateczny termin na zgłoszenie wszelkich wniosków dowodowych, po upływie którego postępowanie zostanie zakończone, a sprawa przejdzie w etap wyrokowania. Nigdy jednak chęć prowadzenia procesu $\mathrm{z}$ zachowaniem ram czasowych przewidzianych prawem ${ }^{18}$ nie może doprowadzić do ograniczenia prawa do sprawiedliwego procesu, nawet gdy dotyczy to pieniacza sądowego.

\section{Pieniactwo sądowe - doświadczenia Sądu Metropolitalnego w Lublinie}

Analiza akt sądowych procesów o nieważność małżeństwa pozwala na stwierdzenie, iż również $\mathrm{w}$ tego typu procesach występują pieniacze sądowi. Badaniu poddano sprawy toczące się od 1930 r. Część dokumentów została niestety zniszczona w czasie okupacji niemieckiej, jednak zachowane akta dostarczają wiedzy na temat działań pieniaczy sądowych. Poddane

dopuścić dowód odrzucony przez sędziego, sam sędzia powinien sprawę jak najszybciej rozstrzygnąć".

17 Kan. 1553 KPK: „Sędzia ma prawo ograniczyć zbyt wielką liczbę świadków”.

18 Kan. 1453 KPK: „Sędziowie i trybunały winni się troszczyć, by jak najszybciej, z zachowaniem sprawiedliwości, zakończyć wszystkie sprawy tak, by w trybunale pierwszej instancji nie przeciągały się powyżej roku, zaś w trybunale drugiej instancji powyżej sześciu miesięcy". 
analizie sprawy pozwoliły na wyselekcjonowanie tych, w których pieniactwo sądowe było wynikiem warcholstwa oraz zaburzeń chorobowych.

Niewątpliwie jednym z najbardziej ewidentnych przykładów pieniactwa sądowego $\mathrm{w}$ typie warcholstwa jest sprawa Jana M. ${ }^{19}$, który 8 marca 1943 r. ponownie zaskarżył ważność swojego małżeństwa zawartego z Bronisławą R. Wcześniej proces ten zakończył się już dwoma negatywnymi wyrokami. Mimo starań, a także gróźb, że upubliczni swoją sprawę, po raz kolejny wydano wyrok negatywny, który potwierdzony został przez trybunał drugiej instancji. Wobec takiego obrotu sprawy, powód złożył pisemną skargę na działanie Sądu Biskupiego w Lublinie do Sekretariatu Prymasa Polski w Warszawie. W odpowiedzi otrzymał pismo, w którym został poinformowany, iż prymas nie widzi potrzeby ingerowania w postępowanie toczące się przed Sądem Biskupim. W rezultacie licznych skarg ze strony powoda, na polecenie biskupa lubelskiego została sporządzona szczegółowa relacja ze spraw małżeńskich i kontaktów powoda z trybunałem. W obszernym piśmie oficjała znajdują się informacje, iż powód terroryzował skład sędziowski, co doprowadziło nawet do rezygnacji jednego z jego członków. Ponadto oficjał stwierdził, że „[...] sprawa napotyka na trudności, gdyż nikt nie chce przyjąć roli przewodniczącego, ani też żaden adwokat patronować sprawie" ${ }^{20}$. Na podstawie akt ukazuje się charakterystyka powoda, który chciał „rozwodu”, a swój zamysł realizuje "dopiero w okresie wojny, kiedy jest u szczytu bogactwa, licząc że pieniądze zrobią wszystko". Ponadto "Jan M. to człowiek zawzięty, złośliwie mściwy i bardzo natarczywy, gotów do daleko idących kroków, kolidujących nawet z normami prawa i etyki, byle tylko dopiąć swego celu. Trzyma się on zasady, że do wszystkiego, nawet rzeczy świętych, podchodzić trzeba po kupiecku: «nie pomogą Kościuszki, Poniatoskie [sic - G.B.], Górale ${ }^{21}$, pójdę naprzód, nie dam się wykiwać»", tak kończy jeden z listów do adwokata (wyciąg z postanowienia prokuratury o umorzeniu skargi Jana M. na wiadomych księży). Ponadto w postępowaniu swoim Jan M. posługuje się groźbą, szantażem i oszczerstwami, czego dowodem były ciągłe depesze, nachodzenie w mieszkaniu i zaczepianie na ulicy pracowników sądu, proponowanie im łapówek, a gdy to

19 [Akta sprawy], Archiwum Sądu Metropolitalnego Lubelskiego (dalej: ASML), sygn. 81/1943/II instancja.

20 Tamże.

21 Potoczne nazwy banknotów będących wówczas w obiegu - przypis autora. 
nie odnosiło skutku fałszywe oskarżanie ich do władz tak duchownych jak i świeckich. Co więcej, w pieniactwie swoim posuwał się nawet tak daleko, że nie mogąc wymusić dla siebie korzystnego wyroku zdemolował pomieszczenia kurii i usiłował dokonać zamachu na jednego z pracowników trybunału. W konsekwencji tego nikt ze sprawą Jana $\mathrm{M}$. nie chciał mieć nic wspólnego. Jak wynika z dalszej treści pisma, powód osobiście udaje się do biskupa Fulmana internowanego w Nowym Sączu, aby ten wpłynął na decyzję trybunału, a także „inspirowany przez adwokata M., skarży ks. K. i M. przed prokuratorem stawiając wciąż te same kłamliwe zarzuty". Prokuratura umarza postępowanie, choć

poważny cień w dochodzeniu rzucony został na etykę adwokacką ks. B.M., który łudził Jana M. wygraną i chcąc przed klientem usprawiedliwić fałszywie pojętą swą bezinteresowność wyciągnął od Jana M. drobne kwoty dla siebie, łudząc go, że incognito przekaże je w niedostatku żyjącemu jak na owe czasy ks. K. ${ }^{22}$

Kuria również przeprowadziła postępowanie administracyjne, które ponad wszelką wątpliwość wykazało, iż wspomniany karalnego przestępstwa nie popełnił. Ksiądz K. żadnych pieniędzy nie przyjął, a „narzucone mu przez ks. M. pończochy w ilości około tuzina miały charakter tylko daru koleżeńskiego, beż żadnej łączności ze sprawą M. By wszakże nie ściągnąć na siebie nawet podejrzeń, ks. K. oddał je biednym, w dowód czego przedłożył kurii pokwitowanie". Ponadto, powód pisał do biskupa, iż rzekomo ks. K. miał przekazać mu przez adwokata ks. M. słowa „powiedz M., żeby wniósł drugi raz pozew z innego tytułu i sprawę mu szybko przeprowadzę". Oczywiście, ks. M. poniósł konsekwencje swojego nieetycznego zachowania i został skreślony z listy adwokatów na mocy decyzji biskupa Fulmana, z tym że mógł dokończyć już rozpoczęte sprawy, jednak bez możliwości popierania apelacji. W tym samym czasie w II instancji toczyła się druga sprawa małżeńska powoda Jana M. W jego opinii za niepowodzenia w prowadzonych przez niego procesach odpowiada ks. K., choć był on w czasie trwania pierwszego procesu tylko notariuszem. Co więcej, Jan. M. znalazł wsparcie i pomoc w osobie adwokata M.M., który słynął z niechęci do ks. K.

Będąc przekonany, że gdy pozbędzie się ks. K., z innymi sędziami da on sobie łatwo radę / o czym z resztą jawnie nie raz mówił/, w pierwszych dniach paź-

22 [Akta sprawy], ASML, sygn. 81/1943/II instancja. 
dziernika 1944 roku nasyła późnym wieczorem na mieszkanie ks. K. trzech uzbrojonych osobników, którzy pod groźbą zastrzelenia wymuszają na nim przysięgę zrzeczenia się stanowiska, co z resztą obiecali sprawdzić. Oczywiście ks. K. groźby się nie uląkł i pozostał nadal, zaś Jan M. oraz napastnicy, rzekomo jego podwładni, uciekli na zachód przed aresztowaniem za podziemną działalność ${ }^{23}$.

Opisane zachowanie powoda w trakcie procesów potwierdził w swoim piśmie do prokuratora kanclerz kurii, a także oficjał sądu w piśmie do biskupa lubelskiego ${ }^{24}$.

Powyżej przedstawiona została sprawa, w której pieniactwo strony doprowadziło bezpośrednio do zagrożenia życia i zdrowia pracowników sądu.

W innym z procesów, wiele lat później, sędzia przewodniczący również padł ofiarą gróźb, choć tym razem ze strony ojca pozwanej, która skutecznie przedłużała postępowanie. Najpierw wnosiła o zmianę właściwości sądu, a gdy to nie przyniosło skutku, składała nowe wnioski i pisma. W listopadzie 2004 r. Grzegorz A. zaskarżył ważność swojego małżeństwa z Wiolettą A., wskazując jako podstawę nieważności niezdolność kobiety z przyczyn natury psychicznej do podjęcia i wypełnienia istotnych obowiązków małżeńskich, co spowodowane było przesadną więzią pozwanej z rodzicami. Powód poinformował sąd, iż obawia się stawić na przesłuchanie w siedzibie trybunału, ponieważ ojciec pozwanej groził „że wypali mu oczy, oblewając twarz kwasem”. Zastraszał on również świadków zgłoszonych przez powoda. W dniu przesłuchania powód stawił się wraz z kolegą, ponieważ bał się ewentualnego spełnienia gróźb przez ojca pozwanej. Pozwana, która wzięła udział w procesie, początkowo uniemożliwiała prowadzenie czynności wskazując, iż nie mieszka pod podanym przez powoda adresem, ale w miejscowości K., która znajduje się w innej diecezji, przez co Sąd Metropolitalny Lubelski nie jest właściwy do rozpoznawania tej sprawy. Kierując coraz to nowe pisma dotyczące faktycznego miejsca zamieszkania, starała się o przeniesienie właściwości do Sądu Biskupiego w Kielcach. Nie podejmowała jednak korespondencji kierowanej na wskazany przez nią adres. Podczas osobistej rozmowy z przewodniczącym trybunału krzyczała, że „pójdzie do [arcybiskupa]

23 Tamże.

24 Zob. [akta sprawy], ASML, sygn. 81/1943/II instancja; G. Bzdyrak, Sąd Biskupi w Lublinie pod okupacja niemiecka 1939-1944, Lublin 2018, s. 284-286. 
i wszystko załatwi”. Wychodząc z sądu twierdziła, że „napisze do Warszawy i tego tak nie zostawi". W poczekalni sądowej przewodniczącego zaatakował również ojciec pozwanej, który obrzucając go wulgaryzmami, groził pozbawieniem życia oraz "pokazaniem jak się załatwia sprawy”. Pozwana nie reagowała na naganne zachowanie ojca. W sprawie przesłuchano świadków oraz powołano biegłego sądowego psychologa celem sporządzenia opinii psychologicznej na temat osobowości stron. Pozwana nie stawiła się na badanie i nie usprawiedliwiła swojej nieobecności. Biegły zauważył przede wszystkim u pozwanej cechy osobowości niedojrzałej, na co wskazuje jej agresja, zależność od rodziców, brak umiejętności pójścia na kompromis. Ponadto biegły podkreślił, iż nawet wobec faktu definitywnego rozstania z powodem i braku chęci naprawienia tych relacji, pozwana nie wyrażała zgody na rozwód cywilny - „nie chciała z nim być, ale nie wolno mu ułożyć sobie życia zgodnie z prawem. W czasie trwającego procesu oskarżyła sędzię prowadzącą sprawę, a adwokat wycofał się z pracy na jej rzecz". Oczywiście pozwana nadal przedłużała postępowanie wnosząc o sporządzenie nowej opinii psychologicznej po przeprowadzeniu badania w Sądzie Biskupim w Kielcach. Mimo przychylenia się do jej prośby, nie stawiła się na to badanie. Jak wynikało z notatki sporządzonej przez notariusza, pozwana przebywała za granicą. Sąd ostatecznie orzekł nieważność zaskarżonego małżeństwa. Proces trwał 33 miesiące w I instancji ${ }^{25}$.

Podobnie postępowanie przedłużał pozwany Jerzy G. Jego żona Jadwiga G. zaskarżyła ważność małżeństwa we wrześniu 2004 r. Po odebraniu wezwania na przesłuchanie, wystąpił on z prośbą o przełożenie terminu o 2 miesiące, ponieważ obecnie jest skupiony na przygotowywaniu pracy magisterskiej, której "temat jest nowy (brak jakiejkolwiek literatury) i wymaga dużego zaangażowania w jego opracowanie". Jednocześnie bardzo szczegółowo, ze wskazaniem nawet dokładnych godzin, opisał kiedy otrzymał awizo, a kiedy powziął wiadomość o treści wezwania. Równocześnie pozwany dołączył odpis prośby/skargi skierowanej do jednego z biskupów pomocniczych archidiecezji lubelskiej. Skarżył się, że nie będzie mógł uczestniczyć w przesłuchaniach świadków, co „uniemożliwi mu dowodzenie kłamstw zawartych w pozwie” i prosił biskupa o ingerencję. Swój list zakończył „Pan nasz Jezus Chrystus powiedział przed Piłatem: przyszedłem po to, żeby dać świadectwo prawdzie".

25 Zob. [akta sprawy], ASML, sygn. 5769/2004/I instancja. 
Oczywiście jego zarzuty były zupełnie bezpodstawne, ponieważ przepisy prawa kanonicznego nie dopuszczały możliwości uczestniczenia strony w przesłuchaniu świadków. Pozwany odbierał to jednak jako ograniczenie jego praw do obrony. Podczas spotkania z przewodniczącym czynił mu zastrzeżenia wobec jego pracy i pouczał co do czynności, które powinny zostać podjęte. Wobec stawianych zarzutów, sędzia złożył wniosek o wyłączenie go ze sprawy. Wniosek został uwzględniony. Pozwany wniósł bardzo obszerną odpowiedź na skargę, składającą się z dwóch części, a liczącą łącznie 31 stron. Pierwszą część odpowiedzi przedłożył podczas przesłuchania co skutkowało koniecznością odroczenia terminu, z uwagi na brak możliwości zapoznania się przez sędziego z jej treścią. Jednocześnie przewodniczący wyznaczył pozwanemu miesięczny termin na złożenie zapowiedzianej drugiej części odpowiedzi. W międzyczasie pozwany doręczył wniosek o przedłużenie tego terminu. Podczas badania psychologicznego pozwany wskazuje, że

czuje się oszukany przez żonę, ale również przez Kościół. Powódka nigdy nie doceniała jego poświęcenia dla dobra rodziny co przypłacił rozstrojem zdrowia [...]. W ocenie psychologicznej pozwany jawi się jako osoba skoncentrowana na sobie, infantylna w swoich oczekiwaniach wobec siebie i innych. Żąda poświecenia, uwagi i aprobaty ze strony otoczenia. Reaguje urazą i wrogością na wymagania stawiane mu przez otoczenie. Ujawnia silną postawę obronną wobec własnych trudności osobowościowych, nie przyznając się do większych konfliktów ani do drobnych wad czy niedociągnięć. Silne i dobrze wyrobione mechanizmy obronne, mimo istniejących poważnych problemów i sytuacji konfliktowych, w których się znalazł, zapewniają mu dobre samopoczucie i wysoką samoocenę bez lęku czy niepokoju, który pojawia się zazwyczaj w takich sytuacjach. W sytuacjach frustracyjnych, napotykając na różne trudności i niepowodzenia, pozwany wykazuje skłonność do obwiniania za nie innych a nie siebie, a więc może reagować agresją skierowaną na zewnątrz. Pozwany wykazuje cechy osobowości paranoidalnej, takie jak: sztywność, podejrzliwość, nadwrażliwość, zazdrość, tendencję do oskarżania innych i przypisywania im wrogich zamiarów ${ }^{26}$.

Pozwany podczas zapoznawania się z zebranym materiałem dowodowym, kilkakrotnie wnosił o przedłużenie terminu publikacji akt, ,,z uwagi na dużą ilość zarzutów, którą chce przedstawić". W międzyczasie ponownie złożył skargę tym razem do arcybiskupa lubelskiego, z prośbą o po-

${ }^{26}$ [Akta sprawy], ASML, sygn. 5745/2004/I instancja. 
moc $\mathrm{w}$ dochodzeniu swoich praw w procesie o stwierdzenie nieważności małżeństwa. Doręczył również obszerne pismo wraz z załącznikami, zawierające zarzuty do opinii biegłego sądowego psychologa i zgromadzonego materiału dowodowego. Pismo rozpoczął cytatem „jeżeli szukasz w człowieku zła, zawsze je znajdziesz". Sąd orzekł nieważność zaskarżonego małżeństwa. Proces trwał 20 miesięcy w pierwszej instancji ${ }^{27}$.

W kolejnej sprawie, którą poddano analizie ${ }^{28}$, u pozwanej zdiagnozowano zaburzenia psychiczne - schizofrenię. Trybunał nie miał wątpliwości, iż zachowanie pozwanej, udokumentowane pismami urzędowymi i opiniami psychologiczno-psychiatrycznymi, uniemożliwiało stronom wspólne pożycie, zwłaszcza, iż pozwana nie chciała podjąć leczenia. Jednak choroba psychiczna nie miała wpływu na ważność tego małżeństwa, gdyż jej objawy ujawniły się dopiero kilka lat po ślubie, a więc nie czyniły pozwanej niezdolną do podjęcia istotnych obowiązków małżeńskich w chwili zawierania zaskarżonego małżeństwa. Pozwana mimo zadeklarowania chęci udziału w procesie odmówiła złożenia zeznań. Powoływała się na znajomości z duchownymi, jak również nakazywała, aby sąd odrzucił skargę powodową. Zapowiedziała, że „odnośnie niniejszego procesu złoży doniesienie do prokuratury”. Ponadto, złożyła pismo z „wnioskiem o wykluczenie z postępowania księży: [...], ze względu na ich nieuczciwość i istniejący konflikt interesów - prywatne zaangażowanie w sprawy po stronie męża [...] oraz o wykluczenie ze wspólnoty Kościoła zaangażowanych w przestępstwa - wymienionych księży i osoby świeckie". Kopie pisma wysłała do wiadomości wielu hierarchów, włącznie z papieżem oraz kilkudziesięciu innych osób, w tym proboszczów parafii w Lublinie. Liczne składane przez nią pisma były niespójne i nielogiczne. Niewątpliwie objawy chorobowe utrudniały pozwanej prawidłową ocenę rzeczywistości. W toku procesu pozwana namawiała świadków, aby nie składali zeznań, zastraszała ich. Kierowała również groźby wobec sędziów. Powołany w sprawie biegły sądowy psycholog wskazał, iż pozwana cierpi najprawdopodobniej na schizofrenię paranoidalną, a ponadto zauważył, u niej innego rodzaju zaburzenia - $\mathrm{w}$ typie mieszanym, osobowości anankastycznej i histrionicznej.

W ostatniej z analizowanych spraw ${ }^{29}$ powód Wiesław Ł. wykazywał objawy psychozy. Zaskarżył on ważność swojego małżeństwa zawar-

\footnotetext{
27 Zob. tamże.

28 Zob. [akta sprawy], ASML, sygn. 7906/2015/I instancja.

29 Zob. [akta sprawy], ASML, sygn. 5049/2000/I instancja.
} 
tego z Krystyną Ł. Istotnym jest, iż pomiędzy stronami toczyły się już liczne sprawy sądowe, m.in. o znęcanie się przez powoda nad rodziną. W trakcie tych postępowań, na zlecenie prokuratury powód był badany psychiatrycznie. Biegli stwierdzili, iż cierpi on na uporczywe zaburzenia urojeniowe:

opiniowany uważa, że stał się osobą wybraną do realizacji wielkich religijnych zamierzeń. Swoje losy porównuje do życiorysów świętych. [...] jest sztywny i nieustępliwy, ponieważ jego losami kieruje Bóg za pośrednictwem licznych wizjonerów, błogosławieństw, przekazów, wobec których jest całkowicie bezkrytyczny, jest przekonany o własnej racji ${ }^{30}$.

Powód nie dostrzegał jednak swojej choroby wskazując, iż to członkowie jego rodziny są chorzy psychicznie. Oskarżał żonę oraz dzieci o kradzież pieniędzy i zażywanie narkotyków. Żadne z tych oskarżeń nie zostało udowodnione. Podczas procesu wskazywał, iż pozwana na polecenie arcybiskupa wniosła sprawę o jego ubezwłasnowolnienie. W toku procesu powód wniósł prośbę o wycofanie sprawy, argumentując to wolą Jezusa Chrystusa, który objawił mu się za pośrednictwem wizjonerki. Ponadto twierdził, iż arcybiskup rozpowiada o nim „po całej diecezji, a nawet w Kophenchadze [sic-G.B.]”, że jest chory psychicznie. Po pół roku wycofał swoją prośbę wskazując, że został oszukany przez wizjonerkę. Trybunał powołał biegłego psychiatrę celem wydania opinii psychiatrycznej na temat powoda. Biegły zauważył, iż „powód przejawia wrażliwość na niepowodzenia, pamiętliwość uraz, nawracające nieuzasadnione podejrzenia dotyczące wierności małżonki, żywienie spiskowych przekonań dotyczących bezpośredniego otoczenia, obficie koresponduje z osobami znaczącymi społecznie z pobudek roszczeniowych". W ocenie biegłego u powoda rozpoznaje się osobowość zaburzoną typu paranoicznego, z cechami fanatyzmu, pieniactwa oraz sensytywności. Podejrzliwość oraz skłonność powoda do nastawień urojeniowych i doszukiwania się spisków, wskazuje na zaburzenia urojeniowe. Oczywiście powód nie zgadzał się z wnioskami biegłego zawartymi w opinii i złożył obszerne pismo z zarzutami, do których dołączył liczne załączniki bez wartości merytorycznej dla sprawy. Sąd uznał, iż udowodniono nieważność zaskarżonego małżeństwa, a na powoda nałożono klauzulę, zgodnie z którą nie mógł on zawrzeć małżeństwa sakramentalnego bez zgody 
ordynariusza miejsca, który uprzednio zasięgnie opinii biegłego sądowego psychologa lub psychiatry. Tę decyzję powód również zakwestionował i wystosował do arcybiskupa lubelskiego prośbę, aby ten wyraził zgodę na zawarcie przez niego małżeństwa bez konieczności zasięgnięcia wymaganej opinii. Wskazał, że jeżeli arcybiskup nie przychyli się do jego petycji, to „zaprzestanie dalszych starań, żyjąc na podstawie prywatnego ślubu, a Jezus Chrystus znając jego szlachetne intencje osądzi sprawiedliwie manipulantów". Arcybiskup nie uwzględnił żądania powoda. Proces trwał 15 miesięcy ${ }^{31}$.

\section{Zakończenie}

Działania pieniaczy sądowych niewątpliwie utrudniają funkcjonowanie wymiaru sprawiedliwości. Zdarza się, iż stanowią nawet zagrożenie dla życia i zdrowia pracowników sądów. Nie można jednak pozbawić pieniacza prawa do sądu i dochodzenia swoich praw. Zachowania pieniaczy są kłopotliwe dla wymiaru sprawiedliwości, a składane przez nich pisma, wnioski i odwołania, niejednokrotnie nie opierają się na żadnych podstawach prawnych, muszą być jednak rozpatrywane, mimo iż wpływa to na wydłużenie czasu trwania procesów.

Sądownictwo kościelne, tak samo jak sądownictwo powszechne, narażone jest na działanie pieniaczy sądowych. W większości spraw o stwierdzenie nieważności małżeństwa jednym z dowodów jest opinia biegłego sądowego psychologa lub psychiatry, który stosując odpowiednio dobraną metodę badań potrafi określić zaburzenia osobowości strony procesowej. Często już na etapie wstępnym procesu, doświadczeni pracownicy sądu mogą stwierdzić, iż dany petent jest pieniaczem sądowym. Takie rozpoznanie jest niezwykle istotne, ponieważ wpływać będzie chociażby na sposób przesłuchiwania takiej osoby. Konieczne jest wykazanie odpowiedniej cierpliwości oraz zachowanie powagi. Nie można bowiem zapominać, iż w większości przypadków, pieniactwo związane jest z zaburzeniami psychicznymi, a więc w sprawie bierze udział osoba chora. Ponadto, rolą procesu o nieważność małżeństwa jest dojście do prawdy obiektywnej o zaskarżonym małżeństwie. Nie można więc lekceważyć

31 Zob. tamże. 
petenta, który choć w sposób „specyficzny”, próbuje jednak dowieść pewnych racji co do swojego małżeństwa. Nie należy oczywiście dopuścić, aby osoba owładnięta obłędem pieniaczym sterowała procesem i wymuszała na sędziach określone decyzje, zgodne z jej oczekiwaniami. Trzeba pamiętać, że lekceważenie pieniacza, wywoła jego dodatkową "aktywność" spowodowaną przeświadczeniem, że pracownicy wymiaru sprawiedliwości również spiskują przeciwko niemu.

Słowa kluczowe: pieniactwo, zaburzenia osobowości, proces o stwierdzenie nieważności małżeństwa, schizofrenia, urojenia, psychoza, warcholstwo, paranoje

\section{Bibliografia}

\section{Źródła prawa}

Konstytucja Rzeczypospolitej Polskiej z dnia 2 kwietnia 1997 r., Dz. U. z 1997 r. Nr 78, poz. 483 z późn. zm.

Codex Iuris Canonici auctoritate Ioannis Pauli PP. II promulgatus. Kodeks Prawa Kanonicznego, przekład polski zatwierdzony przez Konferencję Episkopatu, Poznań 1984.

Franciszek, List apostolski motu proprio "Mitis Iudex Dominus Iesus” reformujacy kanony Kodeksu Prawa Kanonicznego dotyczace spraw o orzeczenie nieważności matżeństwa (15.08.2015), Tarnów 2015 [zmiany weszły w życie 8 grudnia 2015 r.].

\section{Źródła archiwalne}

Archiwum Sądu Metropolitalnego Lubelskiego, sygn. 81/1943/II instancja; 5049/2000/I instancja; 5745/2004/I instancja; 5769/2004/I instancja; 7906/ 2015/I instancja.

\section{Literatura}

Bzdyrak G., Są Biskupi w Lublinie pod okupacją niemiecka 1939-1944, Lublin 2018.

Jagiełło D., Pieniacze sądowi i ich funkcjonowanie w praktyce wymiaru sprawiedliwości, „Medyczna Wokanda” 2014, nr 6, s. 185-192.

Pawluk T., Prawo kanoniczne według Kodeksu Jana Pawła II, t. 4. Doczesne dobra Kościoła. Sankcje w Kościele. Procesy, Olsztyn 1990.

Paździor S., Przyczyny psychiczne niezdolności osoby do zawarcia małżeństwa w świetle kan. 1095 n. 3, Lublin 2009².

Szymczak M. (red.), Słownik języka polskiego, t. 2, Warszawa 1992.

Szymczak M. (red.), Stownik jezyka polskiego PWN, t. 3, Warszawa 1998. 
Soroko E., Paranoiczne zaburzenia osobowości, [w:] L. Cierpiałkowska, E. Soroko (red.), Zaburzenia osobowości. Problemy diagnozy klinicznej, Poznań 2017, s. 97-118. Wojtasik J., Kwerulant sądowy, czyli różne oblicza pieniactwa, Internetowy Serwis Informacyjny Prokuratury Okręgowej w Zielonej Górze, http:/ /www.zielona-gora.po.gov.pl/index.php?id=36\&ida=2891 [dostęp: 29.03.2019 r.].

\section{COURT BERRATRY ON THE EXAMPLE OF CASES EXAMINED BY THE METROPOLITAN COURT IN LUBLIN}

\section{Sum mary}

The activities of court barraters hinder the functioning of judiciary, including church judicature in the cases regarding the annulment of marriage. The purpose of the marriage annulment proceedings is to arrive at the objective truth about the challenged marriage. A petitioner who tries to prove certain reasons for his marriage in a "specific" way must not be disrespected. A person overwhelmed with the barratry fever must not be allowed to control the proceedings and force judges to make certain decisions in line with his or her expectations. However, one should bear in mind that in the majority of cases barratry is associated with some mental disorders. Consequently, a sick person is involved in the proceedings, which determines a specific way of conduct on the part of the people involved. There are at least three typical causes of barratry: paranoia, psychosis and rowdiness, with only two of them having a pathological background, while only the third one can be associated with human's personality or character.

Key words: barratry, mental disorders, marriage annulment proceedings, schizophrenia, delusions, psychosis, rowdiness, paranoia

\section{КВЕРУЛЯНСТВО НА ПРИМЕРЕ ДЕЛ, РАССМАТРИВАЕМЫХ В МЕТРОПОЛИТАРНОМ СУДЕ ЛЮБЛИНА}

\section{Резюме}

Действия кверулянтов препятствуют функционированию судебной системы, включая церковную юрисдикцию в случаях признания недействительности брака. Задача процесса признания брака недействительным состоит в том, чтобы прийти к объективной истине о том, что брак оспаривается. Нельзя недооценивать заявителя, который „определенным” образом пытается доказать определенные причины своего брака. Нельзя допускать, 
чтобы человек, пораженный сутяжничеством, контролировал процесс и заставлял судей принимать определенные решения в соответствии с его ожиданиями. Тем не менее, следует помнить, что в большинстве случаев кверулянтство связано с психическими расстройствами, поэтому в дело вовлечен больной, что определяет конкретный порядок действий лиц, участвующих в процессе. Существует по крайней мере три характерных причины сутяжничества: паранойя, психоз и склочничество, только две из которых имеют заболевание, в то время, как только третья связана с личностью или характером человека.

Ключевые слова: сутяжничество, расстройства личности, процес признания недействительности брака, шизофрения, бред, психоз, склочничество, паранойя 
